\title{
WOODEN ORTHODOX CHURCHES IN THE MARAMUREŞ REGION - OPPORTUNITIES AND THREATS OF TOURISM DEVELOPMENT
}

\author{
JAN A. Wendt, ${ }^{1}$ AleXAndru Ilieş, ${ }^{2}$ TOMASZ WiskUlski, ${ }^{3}$ MARIN Ilieş ${ }^{4}$ \\ ${ }^{1}$ University of Gdańsk, Faculty of Oceanography and Geography \\ e-mail: jan.wendt@ug.edu.pl \\ ${ }^{2}$ University of Oradea, Tourism and Sport, Faculty of Geography \\ e-mail: ilies@uoradea.ro \\ ${ }^{3}$ Gdańsk University of Physical Education and Sport, Faculty of Tourism and Recreation \\ e-mail: tomasz.wiskulski@awfis.edu.pl \\ ${ }^{4}$ Babeș-Bolyai University, Faculty of Geography, Cluj-Napoca, Sighetu Marmației Extension \\ e-mail: marin.ilies@ubbcluj.ro
}

\section{\begin{tabular}{l|l} 
JEL CODES & L83, Z32
\end{tabular} \\ KEYWORDS Maramureş, wooden churches, opportunities, threats, tourism development}

ABSTRACT This article is an attempt to determine, analyse and evaluate the most urgent problems of tourism development in Romania illustrated by the case of the Maramureş region. The fieldwork was carried out in the period from 2013 to 2017 . Not only basic statistical analyses regarding tourist traffic in Romania and the region were carried out, but also literature studies allowing for the evaluation of the scale of the problems. The Maramureş region is a real living open-air museum despite growing tourist traffic, located in the northern part of the country. Wooden Orthodox churches with high steeples are particularly remarkable. In 1999, eight of them were included on the UNESCO List of World Cultural and Natural Heritage due to their uniqueness. However, this extraordinary world of wooden architecture and cultural heritage is being under pressure from increasing tourist traffic. Determining the most burning development problems of this region is the main objective of this study. The authors carried out a SWOT analysis aimed at determining opportunities and threats of tourism development, as it has been stated in the title of the article.

\section{Introduction}

"Romania is a country which has had strong ties with Poland for many centuries due to the geographical proximity between the two counties. For more than 300 years Romanian Principality of Moldavia was a direct neighbour of Poland" (Maryański, 1973, p. 5). However, after World War II a negative image of Romania has been widespread in Poland for many years. Nonetheless, 
a continuously growing number of Polish tourists visiting Romania (Table 1) proves that this stereotype is quickly changing into a positive one.

Nowadays, Romania is one of the most attractive tourist destinations in Europe which has not been fully recognised by tourists. There are numerous tourist attractions, both natural and anthropogenic. A strong marketing "Dracula" brand is recognised throughout the whole continent.

Tahle 1. Number of tourists visiting Romania in the period from 2000 to 2016 (in thousands)

\begin{tabular}{lrrrrrc}
\hline $\begin{array}{c}\text { Number } \\
\text { of tourists }\end{array}$ & 2000 & 2005 & 2010 & 2015 & 2016 & $\begin{array}{c}2016 / 2000 \\
(\%)\end{array}$ \\
\hline Total & 5,264 & 5,839 & 7,498 & 9,331 & 10,223 & 194.2 \\
\hline Europe & 5,024 & 5,522 & 7,098 & 8,676 & 9,508 & 189.3 \\
Poland & 102 & 62 & 238 & 355 & 302 & 296.1 \\
\hline
\end{tabular}

Source: based on Romanian Statistical Yearbook, 2016 and Călătoriile internaţionale înregistrate la frontierele României în anul 2016, 2017.

Apart from the capital city, Sibiu, Brasov, Sighisoara, Cluj-Napoca in Transylvania, Bran in Wallachi, Oradea in the Crişana region and Timisoarę in Banat (Ilieş A., Ilieş D.C., Tătar, Ilieş, 2017) are among the most frequently visited Romanian cities. However, the region of Maramureş has become one of the most interesting destinations over the last few years. According to the information by National Geographic Traveler Magazine - Maramureş region was classified in the Top 20 mandatory tourist destinations for 2015, summing up a series of criteria: authenticity, sustainability, cultural richness (Mazilu, Gheogheci, 2015, p. 5).

\section{Objective and research methods}

The Maramureş regions is a real living open-air museum despite growing tourist traffic. It is located in the northern part of the country, near the border with Ukraine (Figure 1). It is an outstanding ethnographic enclave when one can get to know the culture and old Romanian traditions (Bârcă, Dinescu, 1997; Baias, 2013; Baias et al., 2014). It is a region where the traditional wood architecture remained unchanged. Next to some typical modern buildings, wooden churches, houses and richly ornamented gates are still constructed. Wooden Orthodox churches with high steeples are particularly remarkable. They are among the most valuable monuments of the sacral architecture in Europe. In 1999, eight of them were included on the UNESCO List of World Cultural and Natural Heritage due to their uniqueness.

However, this extraordinary world of wooden architecture and cultural heritage is being under pressure from increasing tourist traffic (Ilieș et al., 2018a, 2018b). Determining the most burning development problems of this region is the main objective of this study. This article is an attempt to determine, analyse and evaluate the most urgent problems of tourism development in Romania illustrated by the case of the Maramureş region. The fieldwork was carried out in the period from 2013 to 2017 during several study visits and field trainings. Not only basic statistical analyses regarding tourist traffic in Romania and the region have been done, but also literature studies 


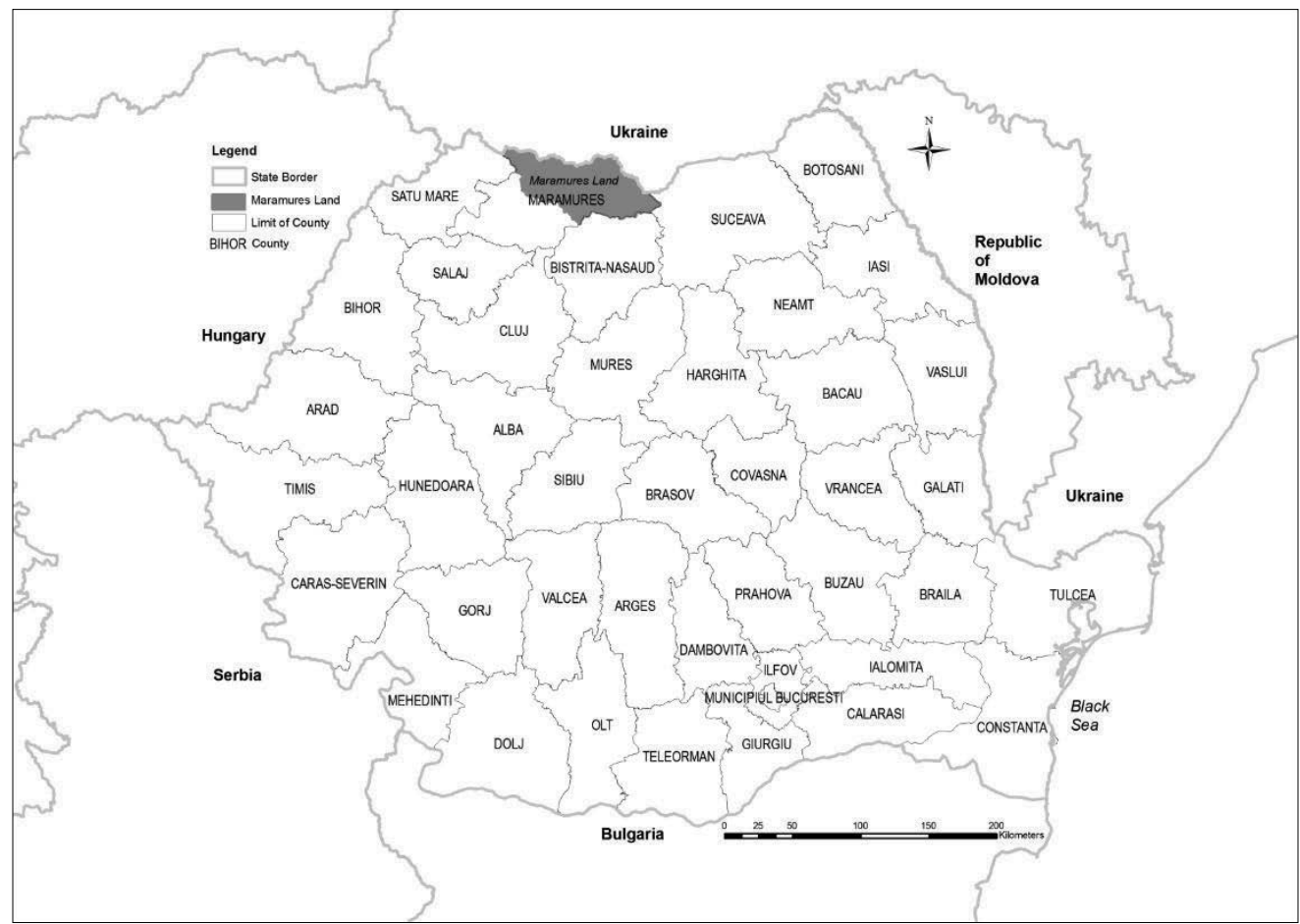

Figure 1. Location of the Maramureș region

Source: Ilieș, Wendt, Ilieș, Herman, Ilieș, Deac (2016).

allowing for the evaluation of the scale of the problems. The Maramureş region itself is well-known to the authors as some of them live there while the others have been visiting it since 2001 while conducting the field trainings (Ilieş, 2006; Ilieş et al., 2009; Ilieş, 2010; Ilieş et. al., 2011). The analyses were based on observations of changes in tourist infrastructure as well as interviews with professional researchers being into the Maramureş tourist market and tourism itself. The authors carried out a SWOT analysis aimed at determining opportunities and threats of tourism development, as it has been stated in the title hereof.

\section{Strengths and weaknesses of tourism development in Maramureş}

The name Maramureş was first mentioned in some Hungarian documents which date back to the end of the $12^{\text {th }}$ century. After World War I Maramureş was divided into two parts: the northern part, inhabited mostly by Ukrainians, was incorporated into Czechoslovakia and the southern one into Romania. In 1940 the region was consolidated within the Hungarian borders and after World War II it was divided again. This time, its northern part was incorporated into Ukraine, being part of the Soviet Union at that time and the southern part returned to Romania (Ilies,, Wendt, 2014). 
The traditional wooden architecture of the Orthodox churches and houses is undoubtedly the main anthropogenic value of the region (Patterson, 2001; Ștef, 2008). There are also treasures of intangible heritage. Local people are proud of their folk songs, dances and music. Almost every valley has its own unique traditional outfit which people are proud of (Ilieș, Wendt, 2015). Still, the main anthropogenic value of the regions is the wooden architecture of the Orthodox churches. The eight of them which were included on the UNESCO List of World Cultural and Natural Heritage in 1999 represents the richness of tourist values. They are usually oak or beech constructions with characteristic tall belfries and one-tier or two-tier roofs covered with shingle. They reflect all the skills and artistry of local craftsmen.

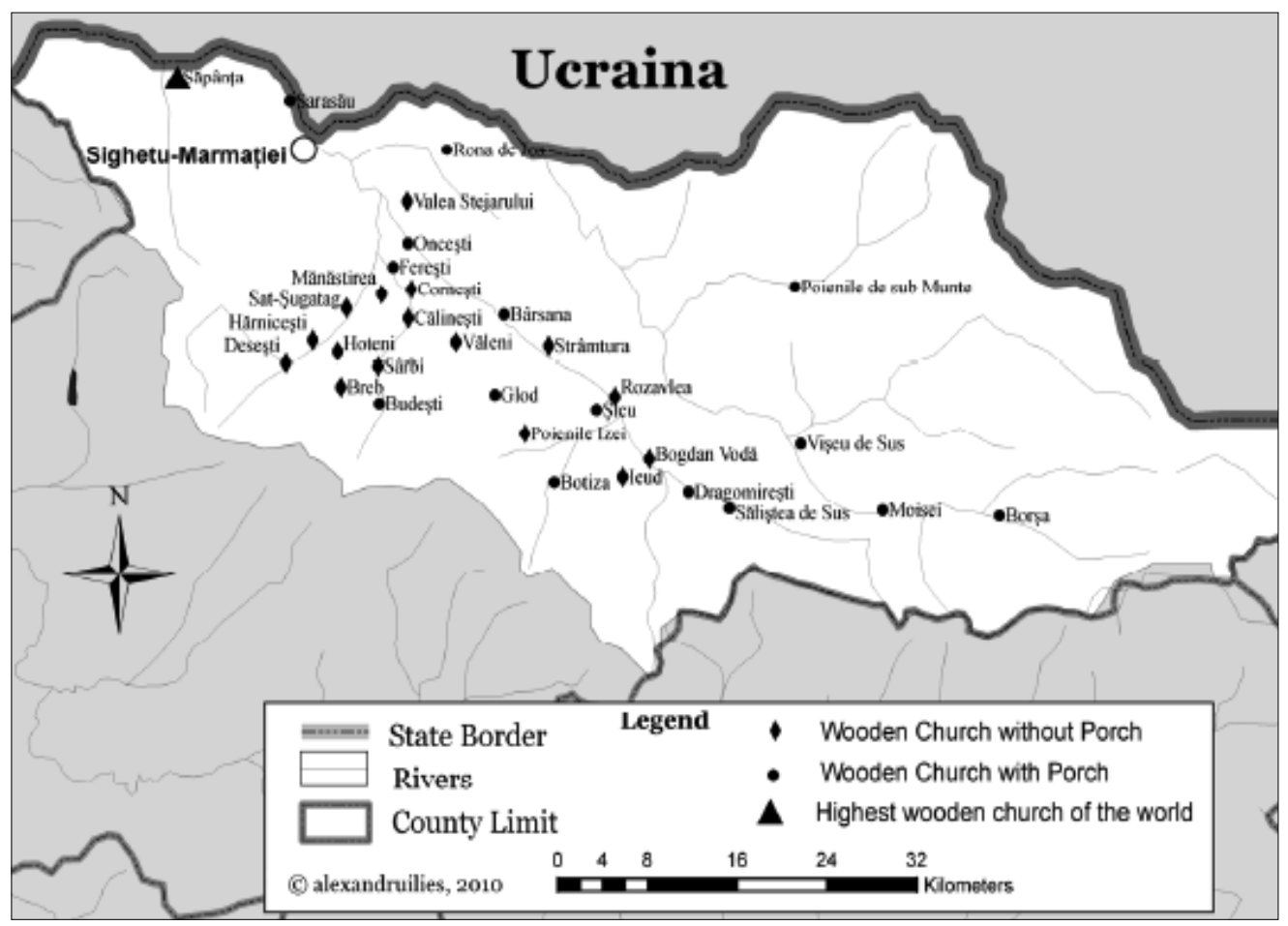

Figure 2. Wooden Churches in the Maramureş region

Source: own study.

Almost a half out of thirty wooden churches have exquisitely carved wooden porches. Moreover, a few of them have four additional small steeples, symbolising that one of the villagers was appointed a member of the board (Table 2). The church in Poienile Izei is one of the oldest buildings in the region. It is not a big one, having a two-tier roof and a valuable interior - a beautiful iconostasis and the eighteen-century 'Last Judgement' scenes by Gheorghe from Dragomiresti on the walls. Another eighteen-century building in Budeşti does not represent a typical architecture 
of the region. With a height of 38 meters it has a two-tier roof over the whole surface of the building with 14 pillars that support it. The belfry has a dome with four steeples. Inside there are well-preserved artworks by A. Ponehalschi and I. Opris. The church in Rogoz is as old as the previous one yet it also has four steeples on an elongated dome. Inside there is a magnificent wooden chandelier, some Biblical scenes and an iconostasis by R.N. Munteanu (1785). In the attic the 'Codex z Ieud' was discovered, claimed the first document written in Romanian, in the Cyrillic alphabet. An open steeple with a balcony is crowned with a small dome. The 1782 iconostasis by A. Ponehalschi depicts the Last Judgement (Porumb, 2005).

Table 2. The Orthodox churches included on the UNESCO List of World Cultural and Natural Heritage

\begin{tabular}{lcc}
\hline \multicolumn{1}{c}{ The Church of } & Year & Location \\
\hline St. Paraskewa "Cuvioasa Paraschiva" & 1604 & Poienile Izei \\
St. Nicolas "Sf. Arhanghel Mihail" & 1643 & Budeşti \\
St. Archangels Michael and Gabriel "Sf. Arhangheli Mihail si Gavril” & 1663 & Rogoz \\
Immaculate Conception of the Most Blessed Virgin Mary "Nasterea Maicii Domnului” & 1717 & Ieud \\
Mary the Mother of God Entering the Church "Intrarea Maicii Domnului in Biserica" & 1720 & Bârsana \\
St. Archangels "Sf. Arhangheli" & 1721 & Şurdeşti \\
St. Paraskewa "Cuvioasa Paraschiva" & 1770 & Deseşti \\
St. Archangels "Sf. Arhangheli" & 1798 & Plopiş \\
\hline
\end{tabular}

Source: own study.

The church in Bârsana was built in 1720 in place of an old one, burnt by Tatars. Initially it was a conventual church, built out of oak wood with a two-tier roof. A unique two-tier porch was added later. The interior painting, executed by T. Hodor and I. Plojodeste, is varied and has baroque influences. The 54-meter high church in Surdesti, built by master Macarie, is considered the highest wooden church in Romania. It has a two-tier roof with a dome and four steeples. There is also a double tiered porch. The church has a stone floor, unlike most wooden churches. The church in Deseşti dates back to the second half of the $18^{\text {th }}$ century. It has an open steeple with a balcony and a two-tier roof. The iconostasis, made by R. Munteanu around the year 1780, shows signs of post-Byzantine art influences and it displays Biblical scenes. Tourists visiting the church are usually most interested in an extraordinary painting depicting people of different nations present at the Last Judgement - the French, Germans, Tatars, Turks or Jews, all wearing traditional clothes. The church in Plopiş was erected at the end of the $18^{\text {th }}$ century. A one-tier roof is topped with a 47-metre slim tower with four small steeples. The iconostasis was allegedly made by S. Zugravulow in 1810 (Man, 2005).

The weaknesses of tourism development in this region include some typical Romanian problems. They are the absence of government support to tourism, weaknesses in destination marketing, unprofessional practices in the tourism business, low standards of services for visitors, inadequate tourism infrastructure (Mazilu, Gheogheci, 2015, p. 5). In Maramureş the major problem is ongoing changes in the cultural landscape. Another weakness of the region is its location in the most impenetrable part of the country with poor quality transport services and infrastructure. 


\section{Opportunities and threats}

The Maramureş region is characterised by an intense pace of tourist infrastructure development. During the period from 2007 to 2016 the number of tourists increased by $175 \%$, similarly to the accommodation capacity (Table 3 ). However, the growing number of visitors and development of accommodation facilities have their price. On the one hand, it can be perceived as a development opportunity, on the other as a threat resulting from excessing the limits of tourist capacity and absorbency.

Table 3. Tourist arrivals (Romanians and foreigners) and the accommodation capacity in the period from 2007 to 2016

\begin{tabular}{|c|c|c|c|c|}
\hline \multirow{2}{*}{ Year } & \multirow{2}{*}{$\begin{array}{c}\text { Number } \\
\text { of tourist arrivals } \\
\text { (in thousands) }\end{array}$} & \multirow{2}{*}{$\begin{array}{l}\text { Accommodation capacity } \\
\text { (number of beds) }\end{array}$} & \multicolumn{2}{|c|}{ Changes $(\%)$ year to previous year } \\
\hline & & & Tourists & Beds \\
\hline 2007 & 108 & 3,635 & $\mathrm{X}$ & $\mathrm{X}$ \\
\hline 2008 & 106 & 3,995 & 98.1 & 109.9 \\
\hline 2009 & 91 & 4,207 & 85.8 & 105.3 \\
\hline 2010 & 92 & 4,368 & 101.1 & 103.8 \\
\hline 2011 & 107 & 4,629 & 115.7 & 106.0 \\
\hline 2012 & 108 & 4,730 & 100.9 & 102.2 \\
\hline 2013 & 109 & 4,805 & 100.9 & 101.6 \\
\hline 2014 & 121 & 4,636 & 111.0 & 96.5 \\
\hline 2015 & 155 & 5,614 & 128.1 & 121.1 \\
\hline 2016 & 189 & 6,451 & 121.9 & 114.9 \\
\hline
\end{tabular}

Source: own study based on: Popescu, Plesoianu (2017).

The already-mentioned changes in the landscape which are directly translated into a significant decrease in quality of tourist spaces are caused by many different factors. One of the most important one, apart from a classic process of modernization, is economic migration of people who usually move to Italy, Spain and France, countries being culturally close to Romania. The migration process triggers money transfers fostering housing investments. The new buildings are most often constructed in the modern architectural style and the landscape they create is a mixture of different Western European landscapes, eclectic and chaotic in its structure.

On the one hand, it is a result of the growing number of tourists followed by the increasing accommodation capacity (Table 3 ) of new hotels and guesthouses, development of the already existing public swimming zones and swimming pools and organization of different events, like fairs or festivals (Ilieş et al., 2017). On the other hand, the demographic factor plays an important role. When the population is ageing and lots of young people migrate there are no people eager to cultivate old traditional crafts like carpentry, wood carving and others which may contribute to preservation of the wooden architecture of the region. Traditional wooden fences, gates, doors and others are being replaced by modern materials allowing to build fast and economically. 
However, there are some positive examples of actions taken in the region which contribute to preservation of the traditional cultural landscape. One of them is construction of a monastery in Bârsana. A new building was built on the outskirts of the village in 1994, right after overthrowing the communist regime. Its exterior resembles old eighteen/nineteen-century Maramureş wooden churches. The complex has a typical wooden gate with a soaring roof. One of the buildings is an Orthodox church of the Twelve Apostles with classic steeples. More and more people returning from emigration modernise their houses in accordance with the requirements of spatial order. In terms of architecture, new hotels and guesthouses more often correspond to the old Maramureş styles and wood, being a traditional construction material, used more and more commonly, both in construction and decoration.

\section{Referenences}

Baias, Ș. (2013). Identificarea, evaluarea și valorificarea patrimoniului cultural de lemn din județul Bihor. Oradea: Editura Universității din Oradea.

Baias, S., Baias, I., Blaga, L., Buhaș, S., Chiriac, A., Ciocan, J., Dăncuş, M., Deac, A., Dragoș, P., Dumitrescu, G., Gaceu, O., Godea, I., Gozner, M., Grama, V., Herman, G., Hodor, N., Hurley, P., Ilieș, D.C., Ilieș, G., Ilieș, M., Josan, I., Leșe, G., Măduța, F., Mojolic, D., Morar, C., Olaru, M., Stașac, M., Stupariu, M., Sturza, A., Ștefănescu, B., Tătar, C., Vârnav, R., Vlaicu, M., Wendt, J.A. (2014). Crisana-Maramures. Geographical atlas of tourism heritage. Oradea: Editura Universității din Oradea.

Bârcă, A., Dinescu, D. (1997). The wooden architecture of Maramureș. București: Humanitas.

Călătoriile internaţionale înregistrate la frontierele României în anul 2016 (2017). România Institutului Național de Statistică. Bucuresti: Editura Institutului Național de Statistică.

Ilieş, A., Hurley, P.D., Ilieş, D.C., Baias, S. (2017). Tourist animation a chance for adding value to traditional heritage: case study in the land Maramures (Romania). Revista de Etnografie si Folclor, 1 (1), 131-151.

Ilieş A., Ilieş D.C., Tătar C., Ilieş M. (2017). The geography of tourism in Romania. In: K. Widawski, J. Wyrzykowski, (eds.), The Geography of Tourism of Central and Eastern European Countries (pp. 329-274). Cham: Springer International Publishing.

Ilieș, A., Wendt, J.A., Ilieș, D.C., Herman, G.V., Ilieș, M., Deac, A.L. (2016). The patrimony of wooden churches, built between 1531 and 2015 in the Land of Maramures, Romania. Journal of Maps, 1 (12), 597-602.

Ilieș, A., Wendt, J.A. (2014). The Evolution of Historical Regions and Borderlands (1916-2011) at the Northern Romanian Ukrainian Border. In: M. Bufon, J. Minghi, A. Paasi (eds.), The New European Frontiers (pp. 289-303). Cambridge: Scholars Publishing.

Ilieș, A., Wendt, J.A. (2015). Geografia turystyczna. Podstawy teorii i zagadnienia aplikacyjne. Gdańsk: Wydawnictwo AWFiS.

Ilieş, A., Ilieş D.C., Josan, I., Grama, V., Herman, G., Gozner, M., Stupariu, M., Gaceu, O., Staşac, M. (2009). Cosău Valley (Maramureş) - Evaluation of Antrophic Patrimony (I). GeoJournal of Tourism and Geosites, 2 (4), $203-216$.

Ilieş, A., Wendt, J., Ilieş, D.C., Josan, I., Herman G. (2011). The Romanian rural architectural heritage from Maramureş Land-Personality, distinctiveness and protection. Studia Universitatis Babes-Bolyai, Geographia, 2, $187-197$.

Ilieș, G. (2006). Țara Maramureșului. Studiu de geografie regional. Cluj-Napoca: Presa Universitară clujeană.

Ilieş, M., Ilieş D.C., Josan, I., Ilieş A., Ilieş, G. (2010). The Gateway of Maramureş Land. Geostrategical Implications in Space and Time. Annals for Istrian and Mediteranian Studies, Series Historia et Sociologia, 2 (20), 469-480.

Ilieş, D.C., Onet, A., Wendt, J.A., Ilieş, M., Baias, S., Herman, G.V. (2018a). Study on microbial and fungal contamination of air and wooden surfaces inside of a historical Church from Romania. Journal of Environmental Biology, 39 (6), 980-984. 
Ilieș, D.C., Oneț, A., Marcu, F., Gaceu, O.R., Timar, A., Baias, S., Ilieș, A., Herman, G.V., Costea, M., Țepelea, M., Josan, I., Wendt, J.A. (2018b). Investigations regarding the air quality in the historic wooden church in Oradea City, Romania. Environmental Engineering and Management Journal, 17 (11), 2731-2739.

Man, G. (2005). Biserici de lemn din Maramureș. Baia Mare: Editura Proema.

Maryański, A. (1973). Rumunia. Warszawa: Państwowe Wydawnictwo Naukowe.

Mazilu, M., Gheorgheci, S. (2015). The perception of Romania as a tourist destination into sustainable development. Annals of the „Constantin Brâncuşi” University of Târgu Jiu, Economy Series, Special Issue, 5-16.

Patterson, J. (2001). Wooden Churches of the Carpathians, A comparative study. New York: East European Monographs.

Popescu, A., Plesoianu, D. (2017). Trends of tourist arrivals and overnight stays in the Maramures county, Romania, 2017-2016 and forecast for 2017-2021. Scientific Papers Series Management, Economic Engineering in Agriculture and Rural Development, 4 (17), 281-291.

Porumb, M. (2005). Biserici de lemn din Maramureș. București: Editura Academiei Române.

Romanian Statistical Yearbook, 2016 (2017). România Institutului Național de Statistică. Bucuresti: Editura Institutului Național de Statistică.

Ștef, D. (2008). Maramureșul brand cultural. Baia Mare: Editura Cornelius.

\section{DREWNIANE CERKWIE REGIONU MARAMUREŞ - SZANSE I ZAGROŻENIA ROZWOJU TURYSTKI}

\author{
SŁOWA KLUCZOWE \\ STRESZCZENIE
}

Maramureş, drewniane kościoły, szanse, zagrożenia, rozwój turystyki

W prezentowanej pracy podjęto próbę wskazania, analizy i oceny głównych problemów rozwoju turystyki w Rumunii na przykładzie historycznego regionu Maramureş. Badania nad problemami rozwoju gospodarki turystycznej w regionie Maramureş przeprowadzono w latach 2013-2017. Poza prostą analizą danych statystycznych dla ruchu turystycznego w Rumunii i w badanym regionie, do oceny wykorzystano literaturę przedmiotu. Region Maramureş, położony na północy kraju, jest prawdziwym żywym skansenem, pomimo wzrastającego z roku na rok ruchu turystycznego. Nadal kultywowane są tradycje drewnianego budownictwa wiejskiego. Cerkiewna architektura drewniana Maramureş jest niezwykła. W 1999 roku osiem z nich, ze względu na ich unikalność, wpisano na Światowego Dziedzictwa Kulturalnego i Przyrodniczego UNESCO. Jednak ten niezwykły świat drewnianej architektury i kulturowego dziedzictwa, tak jak każdy rozwijający się gospodarczo i modernizujący się pod presją wzrastającego ruchu turystycznego region, boryka się z licznymi problemami, których diagnoza stanowi cel niniejszych badań. Podstawą do analizy były obserwacje zachowywania zmian w zagospodarowaniu turystycznym oraz wywiady z profesjonalistami prowadzącymi badania rynku turystycznego i turystyki w Maramureş. W pracy zawarto analizę SWOT wskazującą na tytułowe szanse i zagrożenia dla rozwoju turystyki w regionie. 